\title{
KEDUDUKAN AKTA NOTARIS SEBAGAI AKTA DI BAWAH TANGAN BERDASARKAN UNDANG-UNDANG JABATAN NOTARIS
}

\author{
Oleh : \\ Selamat Lumban Gaol \\ Dosen Tetap Fakultas Hukum Universitas Dirgantara Marsekal Suryadarma Jakarta. \\ aktif di LKBH Unsurya, anggota PERADI (Perhimpunan Advokat Indonesia) dan anggota HKHPM (Himpunan \\ Konsultan Hukum Pasar Modal), serta Mediator bersertipikat dari Mahkamah Agung R.I. \\ Email : (selamatlumbangaol@gmail.com)
}

\begin{abstract}
Abstrak :
Kecenderung umum suatu akta notaris merupakan akta otentik yang dimaksud dalam Pasal 1868 KUH Perdata maupun yang diatur dalam Undang-Undang No. 30 Tahun 2004 Tentang Jabatan Notaris sebagaimana diubah dengan Undang-Undang Nomor 2 Tahun 2014. Permasalahan yang timbul apakah semua akta notaris sudah pasti akta otentik dan apakah akta notaris dapat berubah menjadi akta dibawah tangann?. Untuk menjawab persoalan tersebut dalam penelitian ini digunakan metode penelitian hukum normatif (yuridis normatif) dengan menggunakan data sekunder, dengan pendekatan Undang-Undang (statute approach). Akta Notaris tetap akan menjadi akta otentik apabila dalam proses pembuatannya telah memenuhi syarat formil dan syarat materiil yang diatur dalam UU Jabatan Notaris, dan suatu akta notaris dapat berubah karena terdegradasi menjadi akta dibawah tangan.
\end{abstract}

Kata kunci : Akta, Notaris, Akta Notaris, Akta Dibawah Tangan.

\section{PENDAHULUAN}

\section{A. Latar Belakang Permasalahan}

Kehadiran Notaris sebagai pejabat publik merupakan jawaban atas kebutuhan masyarakat akan kepastian hukum atas setiap perikatan yang mereka lakukan, tentunya perikatan yang terkait dengan interaksi kehidupan sehari-hari dan juga usaha perdagangan. Karena berdasarkan Undang-Undang Jabatan Notaris, ${ }^{1}$

${ }^{1}$ UU No. 30 Tahun 2004 Tentang Jabatan Notaris sebagaimana diubah dengan UU No. 2 Tahun 2014 Tentang Perubahan Atas UU No. 30 Tahun 2004 Tentang Jabatan Notaris, untuk selanjutnya sebagai satu kesatuan dalam penulisan ini cukup disebut dan
Notaris adalah satu-satunya pejabat yang diberi wewenang umum untuk membuat akta perikatan, sebagai suatu akta otentik. ${ }^{2}$

disingkat "UU Jabatan Notaris" atau "UU JN" atau "UU JN (UU No. 30 / 2004 Jo. UU No. 2 / 2014)." Indonesia, Undang-Undang Tentang Jabatan Notaris, UU No. 30 Tahun 2004, Lembaran Negara Republik Indonesia Tahun 2004 Nomor 117, Tambahan Lembaran Negara Republik Indonesia Nomor 4432.; Indonesia, Undang-Undang Tentang Perubahan Atas Undang-Undang Nomor 30 Tahun 2004 Tentang Jabatan Notaris, UU No. 2 Tahun 2014, Lembaran Negara Republik Indonesia Tahun 2014 Nomor 3, Tambahan Lembaran Negara Republik Indonesia Nomor 5491.

${ }^{2} \mathrm{UU}$ Jabatan Notaris, Pasal 1 angka 1 "Notaris adalah pejabat umum yang berwenang untuk 
Secara umum, dipahami bahwa suatu akta notaris merupakan akta otentik yang dimaksud dalam Pasal 1868 KUH Perdata maupun yang diatur dalam UU Jabaran Notaris.

Akta Notaris merupakan dan pengaturan lebih lanjut dari akta otentik yang dimaksud dalam Pasal $1868^{3}$ KUH Perdata, dimana bentuk atau formatnya dan syarat formal maupun materiilnya diatur dan ditentukan dalam UU Jabatan Notaris.

Suatu akta notaris akan berkedudukan sebagai akta otentik apabila akta tersebut dibuat sesuai dengan dan memenuhi ketentuan yang diatur dalam UU Jabatan Notaris. Sebaliknya apabila suatu akta notaris dibuat tidak sesuai dengan dan bertentangan serta melanggar ketentuan yang diatur dalam UU Jabatan Notaris, maka akta tersebut dari semula akta otentik berubah dan turun (terdegradasi) menjadi dan berkedudukan sebagai akta di bawah tangan.

Menelusuri ketentuan yang mengatur kedudukan suatu akta notaris dari semula akta otentik berubah dan turun (terdegradasi) menjadi dan berkedudukan sebagai akta di bawah

membuat akta autentik dan memiliki kewenangan lainnya sebagaimana dimaksud dalam UndangUndang ini atau berdasarkan undang-undang lainnya."

${ }^{3}$ Pasal 1868 KUH Perdata "Suatu AKTA OTENTIK ialah suatu AKTA yang didalam BENTUK yang DITENTUKAN oleh Undang-Undang, dibuat oleh atau dihadapan pegawai-pegawai UMUM yang BERKUASA untuk itu DI TEMPAT di mana AKTA DIBUATnya." tangan, dalam UU Jabatan Notaris menarik untuk dilakukan.

Dari uraian diatas, menarik dan perlu dilakukan pengkajian berkenaan dengan kedudukan suatu akta notaris dari semula akta otentik berubah dan turun (terdegradasi) menjadi dan berkedudukan sebagai akta di bawah tangan berdasarkan Undang-Undang Jabatan Notaris tersebut.is:pe:

Berdasarkan latar belakang masalah tersebut, peneliti melakukan penelitian dengan judul "Kedudukan Akta Notaris Sebagai Akta Dibawah Tangan Berdasarkan Undang-Undang Jabatan Notaris."

\section{B. Rumusan Masalah}

Bertolak dari uraian latar belakang permasalahan tersebut, dapat dirumuskan permasalahan yang akan dikaji dalam penelitian ini dibatasi pada pokoknya sebagai berikut:

1. Bagaimanakah pengaturan keabsahan suatu akta Notaris berdasarkan UU Jabatan Notaris?.

2. Bilamanakah suatu Akta Notaris berkedudukan sebagai akta dibawah tangan berdasarkan UU Jabatan Notaris?.

\section{Tujuan dan Kegunaan Penelitian}

Secara teoritis penelitian ini diharapkan dapat mengembangkan ilmu pengetahuan hukum pada umumnya, khususnya hukum perdata di Indonesia terkait dengan masalah akta Notaris sebagai akta otentik yang terdegradasi (turun) menjadi sebagai akta dibawah tangan. Kemudian diharapkan juga dapat digunakan sebagai referensi yang dapat ikut menunjang ilmu pengetahuan 
khususnya ilmu pengetahuan hukum perdata dan kenotariatan di Indonesia. Selanjutnya penelitian ini diharapkan juga dapat berguna secara praktis, yaitu menjadi pegangan dan pedoman bagi praktisi hukum dan para pencari keadilan untuk mengajukan gugatan berkenaan dengan kedudukan akta Notaris sebagai akta dibawah tangan, serta para Hakim dalam memeriksa, memutus dan mengadili gugatan berkenaan dengan kedudukan akta Notaris sebagai akta di bawah tangan. Penelitian ini juga diharapkan dapat berguna bagi kalangan masyarakat luas ketika hendak mengajukan gugatan ke Pengadilan Negeri.

\section{Studi Pustaka}

\section{Akta Pada Umumnya}

a. Pengertian Akta

Kata akta atau akte berasal dari bahasa latin "acta" yang berarti surat atau tulisan ${ }^{4}$ atau sesuatu yang tertulis untuk bukti. ${ }^{5}$ Sedangkan tulisan (geschrift) menurut AsserAnema sebagaimana dikutif oleh Tan Thong Kie adalah pengemban tanda-tanda baca yang mengandung arti serta bermanfaat untuk menggambarkan suatu pikiran. $^{6}$

Pendapat berbeda dikemukakan oleh R. Subekti, kata akta bukan berarti surat melainkan harus diartikan dengan perbuatan hukum, berasal dari kata acte yang dalam bahasa Perancis berarti perbuatan. ${ }^{7}$

Lebih lanjut R. Subekti dalam perspektif hukum pembuktian menyatakan bahwa suatu akta merupakan suatu tulisan yang memang dengan sengaja dibuat untuk dapat dijadikan bukti bila ada suatu peristiwa dan ditanda tangani. ${ }^{8}$

Sedangkan menurut Sudikno Mertokusumo, akta adalah surat yang diberi tanda tangan atau ditandatangani para pihak yang membuatnya, yang memuat peristiwa yang menjadi dasar daripada suatu, hak atau perikatan, yang dibuat sejak semula dengan sengaja untuk pembuktian. ${ }^{9}$

\section{b. Jenis-jenis Akta}

Dari ketentuan yang diatur dalam Pasal $1867^{10}$ KUH Perdata dapat diketahui bahwa tulisan terdiri atas 2 (dua) macam tulisan yaitu tulisan otentik atau tulisan resmi (authentiek) dan tulisan di bawah tangan (onderhands). ${ }^{11}$
${ }^{4}$ Algra N.E., H.R.W. Gokkel,dkk, Kamus Istilah Hukum Fockema Andreae, Belanda Indonesia, [Fockema Andreas's rechtsgeleerd Handwoordenboek], diterjemahkan oleh Saleh Adi Winata, A Teloeki, H. Boerhanoeddin St Boen, Cet. 1, (Bandung: Binacipta, 1983), hlm. 16.

${ }^{5}$ H.R.W. Gokkel dan N. Van der wal, Istilah Hukum Latin Indonesia, [Juridish Latijn], diterjemahkan oleh S. Adi Winata, A Teloeki, H. Boerhamoeddin St Boen, Cet. 2, (Jakarta: PT Intermasa, 1986), hlm. 10.

${ }^{6}$ Tan Thong Kie, Studi Notariat Dan SerbaSerbi Praktek Notaris, Cet. 2, (Jakarta: PT Ichtiar Baru van Hoeve, 2011), hlm 441
${ }^{7}$ R. Subekti (a), Pokok-Pokok Hukum Perdata, Cet. 15, (Jakarta: PT. Intermasa, 1980), hlm. 29.

${ }^{8}$ R. Subekti (b), Hukum Pembuktian, Cet. 8, (Jakarta: Penerbit Pradnya Paramita, 1987), hlm. 27.

${ }^{9}$ Sudikno Mertokusumo, Hukum Acara Perdata Indonesia, Ed. 6, Yogyakarta: Liberty, 2002, hlm. 120

${ }^{10} \mathrm{KUH}$ Perdata Pasal 1867 "Pembuktian dengan tulisan dilakukan dengan tulisan-tulisan otentik maupun dengan tulisan-tulisan dibawah tangan."

${ }^{11}$ R. Subekti (b), Op.Cit, hlm. 178. 


\section{1) Akta Otentik}

Pengertian dan makna akta otentik diatur dalam Pasal $1868^{12} \mathrm{KUH}$ Perdata dan Pasal $165^{13}$ HIR/Pasal 185 RBg, dengan unsur-unsur sebagai berikut:

a) akta itu harus dibuat oleh atau dihadapan seorang Pejabat Umum

Akta otentik terutama memuat keterangan seorang pejabat, yang menerangkan apa yang dilakukannya dan dilihat dihadapannya. ${ }^{14}$

Sebagai keterangan dari seorang pejabat bahwa apa yang dikatakan pejabat itu adalah sebagai yang dilihatnya dianggap sebagai benar terjadi dihadapannya, maka kekuatan pembuktiannya berlaku bagi setiap orang. Karena akta otentik itu merupakan risalah dari pejabat, maka hanyalah merupakan bukti daripada apa yang terjadi dihadapannya saja. ${ }^{15}$

Pejabat umum yang dimaksud

${ }^{12}$ KUH Perdata Pasal 1868 "Suatu akta otentik ialah suatu akta yang didalam bentuk yang ditentukan oleh undang-undang, dibuat oleh atau dihadapan pegawai-pegawai umum yang berkuasa untuk ditempatkan dimana akte dibuatnya."

${ }^{13}$ HIR Pasal 165 "Akte otentik, yaitu suatu surat yang diperbuat oleh atau dihadapan pegawai umum yang berkuasa akan membuatnya, mewujudkan bukti yang cukup bagi kedua belah pihak dan ahli warisnya serta sekalian orang yang mendapat hak daripadanya, yaitu tentang segala hal, yang tersebut didalam surat itu dan juga tentang yang tercantum dalam surat itu sebagai pemberitahuan sahaja, tetapi yang tersebut kemudian itu hanya sekedar yang diberitahukan itu langsung berhubungan dengan pokok dalam akte itu." Mr R. Tresna, Komentar HIR, Cet. 18, (Jakarta: PT Pradnya Paramita, 2005), hlm. 142.

${ }^{14}$ Sudikno Mertokusumo, Op.Cit., hlm. 123.

${ }^{15}$ Ibid, hlm. 124. adalah pejabat yang diberi wewenang berdasarkan Undang-undang dalam batas wewenang yang telah ditetapkan dengan tegas dan jelas dalam Undang-undang yang bersangkutan, misalnya notaris, hakim, jurusita pada suatu Pengadilan, Pegawai pencatatan sipil (ambtenaar burgerlijke stand) dan sebagainya.

Secara garis besar pejabat yang berwenang membuat akta otentik antara lain sebagai berikut: ${ }^{16}$

(1) Di bidang hukum publik oleh Pejabat Tata Usaha Negara (Pejabat TUN)

Seperti Kartu Tanda Penduduk (KTP), Surat Izin Mengemudi (SIM), Izin Mendirikan Bangunan (IMB), Izin Pergudangan, Passpor dan sebagainya, semuanya dibuat oleh Pejabat TUN. Namun demikian, ada juga akta otentik tertentu yang dibuat oleh Pejabat Yudikatif, seperti Berita Acara Sidang, Surat Penanggalan, Berita Acara Sita, Akta Banding atau Kasasi, yang dibuat oleh Panitera atau jurusita, penetapan atau putusan pengadilan yang dibuat oleh Hakim yang memeriksa, memutus dan

${ }^{16}$ M. Yahya Harahap, Hukum Acara Perdata: Gugatan, Persidangan, Penyitaan, Pembuktian, dan Putusan Pengadilan, Ed. 2, Cet. 1, (Jakarta: Sinar Grafika, 2017), hlm. 644-646. 
Kedudukan Akta Notaris Sebagai Akta Di Bawah Tangan Berdasarkan

mengadili perkara yang bersangkutan.

(2) Di bidang hukum perdata oleh Notaris

Pada umumya akta otentik yang meyangkut bidang perdata, dibuat dihadapan Notaris, sebagaimana dimaksud dan berdasarkan Undang-undang Jabatan Notaris (UU Nomor 30 Tahun 2004 Jo. UU Nomor 2 Tahun 2014).

Akan tetapi dalam hal tertentu bisa juga Pejabat TUN seperti akta nikah dibuat dihadapan Pegawai Pencatatan Nikah (PPN) di Kantor Urusan Agama (KUA) bagi mereka yang beragama Islam dan dihadapan Pegawai Catatan Sipil bagi yang non Islam.

Akta otentik itu dapat dibedakan 2 (dua) bagian besar sebagai berikut: ${ }^{17}$

(a) akta yang dibuat oleh (door) $\quad 18 \quad$ Pejabat (ambtelijke aktan, acte ambtelik, procesverbaal acte, acta relaas)

Akta yang dibuat oleh Pejabat yang diberi wewenang untuk itu

${ }^{17}$ H.R. Daeng Naja, Teknik Pembuatan Akta (Buku Wajib Kenotariatan), Cet. 1, (Yogyakarta: Pustaka Yustisia, 2012), hlm. 15. Sudikno Mertokusumo, Loc.Cit. M. Yahya Harahap, Op.Cit, hlm. 647.

${ }^{18}$ G.H.S. Lumban Tobing, Peraturan Jabatan Notaris Di Indonesia, (Jakarta: PT Erlangga, 1980), hlm. 4. dengan mana pejabat tersebut menerangkan apa yang dilihat serta apa yang dilakukannya.

Pada umumnya akta otentik yang dibuat dihadapan pejabat yang berwenang, berdasarkan

permohonan dari yang berkepentingan.

Namun ada juga tanpa permintaan dari yang berkepentingan, tetapi pembuatannya

dikaitkan dengan fungsi tertentu seperti pembuatan Berita Acara oleh Notaris atau Putusan pengadilan, dibuat berdasarkan pelaksanaan fungsi penegakan hukum yang ditentukan Undang-undang dalam hal ini hukum acara. Jadi inisiatifnya atau kehendak atau keinginan tidak berasal dari orang yang namanya diterangkan dalam akta itu.

(b) akta yang dibuat dihadapan (ten overstaan) 19 Pejabat (aktan overstaan) oleh para pihak yang memerlukannya (partij aktan) atau yang

${ }^{19}$ Ibid 
dibuat oleh para pihak

dihadapan Pejabat

(partij acte).

Akta yang dibuat dihadapan pejabat yang berwenang untuk itu, dengan akta itu pejabat menerangkan juga apa yang dilihat serta dilakukannya.

Para pihak atas kemauan mereka sendiri, datang ke kantor Pejabat. Dihadapan pejabat para pihak memberi atau meyampaikan keterangan sendiri atau keterangan yang disampaikan dapat berbentuk lisan atau tulisan, lalu para pihak meminta kepada pejabat, agar keterangan yang mereka sampaikan dituangkan dalam bentuk akta. Misalnya akta notaris.

b) akta itu dibuat dalam bentuk yang ditentukan oleh Undangundang

Dalam pembuatan akta otentik tersebut, Pejabat terikat pada syarat-syarat dan ketentuan dalam Undang-undang, sehingga hal itu merupakan jaminan dapat dipercayainya pejabat tersebut, maka daripada itu akta otentik itu cukup dibuktikan oleh akta itu sendiri.

c) pejabat umum oleh atau dihadapan siapa akta itu dibuat, harus mempunyai kewenangan untuk membuat akta itu

Pejabat yang membuat akta tersebut berwenang untuk membuat akta otentik tersebut karena jabatan (ambt) baik berdasarkan pengangkatan ataupun karena penunjukan yang diperintahkan / diamanatkan oleh Undangundang.

Pejabat tersebut memang berwenang membuat akta otentik tersebut baik dari jenis dan materi muatan akta otentik dimaksudkan, maupun juga dari segi para pihak yang menghadap atau pihak-pihak yang meminta dibuatkan akta otentik tersebut.

d) Pejabat umum membuat akta dalam daerah / wilayah kerjanya.

Pejabat yang membuat akta tersebut hanya berwenang membuat akta otentik di dalam wilayah kerjanya dan atau di wilayah kedudukannya sesuai dengan yang ditetapkan dalam surat keputusan pengangkatan / penunjukannya berdasarkan ketentuan yang diatur dalam Undang-undang tertentu yang mendasari kewenangan Pejabat tersebut.

2) Surat dibawah tangan

Surat di bawah tangan ialah surat yang sengaja dibuat untuk pembuktian oleh para pihak tanpa bantuan atau tanpa perantaraan 
dari seorang pejabat. ${ }^{20}$

Misalnya surat perjanjian jual beli atas sewa menyewa yang dibuat sendiri oleh kedua belah pihak yang mengadakan perjanjian itu.

\section{Pengertian Akta Notaris Dan Notaris}

Secara umum dapat disimpulkan bahwa akta Notaris adalah akta otentik, yaitu suatu tulisan yang dibuat untuk membuktikan suatu peristiwa atau hubungan tertentu sebagaimana dimaksud dalam Pasal 1868 KUH Perdata. Sebagai suatu akta otentik, maka akta Notaris tersebut memberikan kekuatan pembuktian yang kuat dan sempurna bagi pihak-pihak yang membuatnya termasuk ahli warisnya sebagaimana dimaksud dalam Pasal $1870^{21} \mathrm{KUH}$ Perdata.

Akta Notaris adalah akta autentik yang dibuat oleh atau di hadapan Notaris menurut bentuk dan tata cara yang ditetapkan dalam UndangUndang Jabatan Notaris. ${ }^{22}$

${ }^{20}$ Sudikno Mertokusumo, Op.Cit., hlm. 127. R. Subekti (b), Op.Cit., hlm. 179.

${ }^{21} \mathrm{KUH}$ Perdata Pasal 1870 "Suatu akta otentik memberikan diantara para pihak beserta ahli waris-ahli warisnya atau orang-orang yang mendapat hak daripada mereka, suatu bukti yang sempurna tentang apa yang dimuat didalamnya."

${ }^{22}$ UU Nomor 2 Tahun 2014 Tentang Perubahan Atas Undang-undang Nomor 30 Tahun 2004, Pasal 1 angka 7. Pengertian akta notaris berdasarkan pendapat para ahli, antara lain : a. menurut Liliana Tedjosaputro, Akta notaris memuat pernyataanpernyataan, kesaksian-kesaksian oleh Notaris mengenai perbuatan-perbuatan yang dilakukan oleh Notaris sendiri atau fakta-fakta yang disaksikan Notaris selama berlangsungnya pembuatan akta”. Lihat Liliana Tedjosaputro, Malpraktek Notaris dan Hukum Pidana, (Semarang: CV. Agung, 1991), hlm. 10 ; b. lebih lanjut menurut A. Kohar, suatu Akta Notaris yang merupakan suatu keterangan Notaris dalam kedudukan sebagai pejabat umum menjamin atas adanya: 1 . Kehadiran (para) penghadap. 2. Pada tempat tertentu. 3. Pada tanggal tertentu. 4. Benar (para) penghadap
Notaris adalah pejabat umum yang berwenang untuk membuat akta autentik dan memiliki kewenangan lainnya sebagaimana dimaksud dalam Undang-undang Jabatan Notaris atau berdasarkan Undangundang lainnya..$^{23}$

Kewenangan notaris dalam membuat suatu akta meliputi 4 (empat) hal, yaitu: ${ }^{24}$

a. notaris harus berwenang sepanjang yang menyangkut akta yang dibuat nya itu.

b. notaris harus berwenang sepanjang mengenai orang (-orang) untuk kepentingan siapa akta itu dibuat.

c. notaris harus berwenang sepanjang mengenai tempat dimana akta itu dibuat.

d. notaris harus berwenang sepanjang mengenai waktu pembuatan akta itu.

Selain berwenang membuat akta notaris, notaris berwenang pula untuk

memberikan keterangan sebagaimana tercantum dalam akta tersebut, atau benar terjadi keadaan sebagaimana disebutkan dalam akta. 5. Benar ditandatangani oleh (para) penghadap (untuk akta pihak) sehingga fungsi dari akta tersebut adalah bahwa (para) penghadap dengan adanya tandatangan dan keterangan (fakta) dari Notaris, tidak dapat memungkiri fakta di atas. Lihat A. Kohar, Notaris dan Persoalan Hukum, (Surabaya: PT. Bina Indra Karya, 1985), hlm. 8 ; c. akta notaris, menurut Muhamad Adam, suatu akta akan memiliki suatu karakter yang otentik jika hal itu akan mempunyai daya bukti di antara pihakpihak dan terhadap pihak ketiga maka hal tersebut sebagai suatu tulisan dalam bentuk sedemikian rupa, sehingga merupakan jaminan bagi para pihak bahwa perbuatan-perbuatan atau keteranganketerangan yang dikemukakan memberikan suatu bukti yang tidak dapat dihilangkan. Lihat Muhammad Adam, Notaris Dan Bantuan Hukum, (Bandung: Sinar Baru, 1985), hlm. 8 .

${ }^{23}$ UU Nomor 2 Tahun 2014 Tentang Perubahan Atas Undang-undang Nomor 30 Tahun 2004, Pasal 1 angka 1.

${ }^{24}$ G.H.S. Lumban Tobing, Op.cit., hlm. $42-$ 
sebagai berikut: ${ }^{25}$

1. mengesahkan tanda tangan dan menetapkan kepastian tanggal surat di bawah tangan dengan mendaftar dalam buku khusus. ${ }^{26}$

Pengesahan surat-surat dibawah tangan yang belum ditandatangani diberikan kepada notaris dan dihadapan notaris ditandatangani oleh orangnya, setelah isi suratsurat itu dijelaskan oleh notaris kepadanya, biasanya disebut legalisasi (vide Pasal 1874 dan Pasal 1874 a KUH Perdata). ${ }^{27}$

Pengesahan tanggal dari surat dibawah tangan atas surat yang diberikan kepada notaris yang sudah ditandatangani oleh pihak yang memberikan kepada notaris tersebut, lazim disebut waarmerking. ${ }^{28}$

2. membukukan surat di bawah tangan dengan mendaftar dalam buku khusus.

3. membuat kopi dari asli surat di bawah tangan berupa salinan yang memuat uraian sebagaimana ditulis dan digambarkan dalam surat yang bersangkutan.

4. melakukan pengesahan kecocokan

${ }^{25}$ UU Nomor 2 Tahun 2014 Tentang Perubahan Atas Undang-undang Nomor 30 Tahun 2004, Pasal 15 ayat (2).

${ }^{26}$ UU Nomor 2 Tahun 2014 Tentang Perubahan Atas Undang-undang Nomor 30 Tahun 2004, Penjelasan Pasal 15 ayat (2) sub huruf a "Ketentuan ini merupakan legalisasi terhadap akta di bawah tangan yang dibuat sendiri oleh orang perseorangan atau oleh para pihak di atas kertas yang bermaterai cukup dengan jalan pendaftaran dalam buku khusus yang disediakan oleh Notaris."

${ }^{27}$ G.H.S. Lumban Tobing, Op.cit., hlm. 237 ; Tan Thong Kie, Op.cit., hlm 28.

${ }^{28}$ Ibid. fotokopi dengan surat aslinya.

5. memberikan penyuluhan hukum sehubungan dengan pembuatan Akta.

6. membuat Akta yang berkaitan dengan pertanahan, atau;

7. membuat Akta risalah lelang.

\section{Metode Penelitian}

Metode penelitian ${ }^{29}$ yang dipilih dan dipergunakan dalam penelitian ini adalah metode penelitian hukum normatif (penelitian yuridis normatif $^{30}$ atau sering juga disebut sebagai penelitian hukum doktrinal

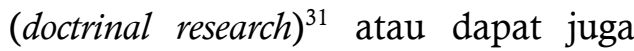

${ }^{29}$ Metode penelitian adalah suatu cara atau jalan untuk memperoleh kembali pemecahan terhadap segala permasalahan dengan menerapkan salah satu metode yang relevan terhadap permasalahan tersebut. Lihat. Joko Subagyo, Metode Penelitian Dalam Teori Dan Praktek, (Jakarta: Rineka Cipta, 2004), hlm. 2

${ }^{30}$ Penelitian hukum normatif atau penelitian hukum kepustakaan adalah penelitian hukum yang dilakukan dengan cara meneliti bahan pustaka atau data sekunder belaka. Penelitian hukum normatif atau penelitian hukum kepustakaan tersebut mencakup penelitian terhadap asas-asas hukum dan penelitian terhadap taraf sinkronisasi vertikal dan horizontal. Lihat: Soerjono Soekanto dan Sri Mamudji, Penelitian Hukum Normatif Suatu Tinjauan Singkat, Ed. 1, Cet. 5, (Jakarta: PT. RajaGrafindo Persada, 2001), hlm. 13-14. Nama lain dari penelitian hukum normatif adalah penelitian hukum doktriner, juga disebut sebagai penelitian perpustakaan atau studi dokumen atau studi kepustakaan. Disebut penelitian hukum doktriner, karena penelitian ini dilakukan atau ditujukan hanya pada peraturan-peraturan yang tertulis atau bahanbahan hukum yang lain. Sebagai penelitian perpustakaan ataupun studi dokumen disebabkan penelitian ini lebih banyak dilakukan terhadap data yang bersifat sekunder yang ada di perpustakaan. Lihat pula Bambang Waluyo, Penelitian Hukum Dalam Praktek, Ed. 1, Cet. 2, (Jakarta: Sinar Grafika, 1996), hlm. 13-14. Penelitian hukum normatif menggunakan studi kasus hukum normatif berupa produk perilaku hukum, misalnya mengkaji suatu undang-undang. Pokok kajiannya adalah hukum yang dikonsepsikan sebagai norma atau kaidah yang berlaku dalam masyarakat dan menjadi acuan perilaku setiap orang. Lihat juga: Abdulkadir Muhammad, Hukum dan Penelitian Hukum, Cet. 1, (Bandung: PT. Citra Aditya Bakti, 2004), hlm. 52.

${ }^{31}$ Penelitian hukum doktrinal, menurut Soetandyo Wighjosoebroto sebagaimana dikutip oleh Bambang Sunggono, terdiri dari (1) penelitian yang 
disebut sebagai penelitian hukum kepustakaan, ${ }^{32}$ dengan melakukan kajian hukum ${ }^{33}$ dengan cara meneliti bahan pustaka.

\section{Kemudian pendekatan penelitian} hukum (approach) ${ }^{34}$ yang digunakan dalam penelitian ini adalah statute approach (pendekatan undang-undang) dengan menelaah regulasi yang berkaitan dengan pengaturan akta Notaris dan jabatan notaris pada umumnya, dan secara khusus kedudukan akta Notaris sebagai akta dibawah tangan. Pendekatan perundang-undangan (statute approach) dilakukan dengan mempelajari dasar

berupa usaha inventarisasi hukum positif, (2) penelitian yang berupa usaha penemuan asas dan dasar falsafah (dogma atau doktrin) hukum positif, (3) penelitian yang berupa usaha penemuan hukum in concreto yang layak diterapkan untuk menyelesaikan suatu perkara hukum tertentu. Lihat Bambang Sunggono, Metodologi Penelitian Hukum (Suatu Pengantar), Ed. 1., Cet. 3, (Jakarta: PT. Raja Grafindo Persada, 2001), hal. 43.

${ }^{32}$ Ronny Hanitijo Soemitro, Metodologi Penelitian Hukum Dan Jurimetri, Cet. ke-3, (Jakarta: Ghalia Indonesia, 1988), hal. 9.

${ }^{33}$ Kajian hukum berarti menggunakan disiplin hukum. Disiplin hukum, menurut Soerjono Soekanto dan Sri Mamudji, adalah suatu sistem ajaran tentang hukum sebagai norma dan sebagai kenyataan (= perilaku atau sikap tindak. Artinya, disiplin hukum menyoroti hukum sebagai sesuatu yang dicita-citakan, maupun sebagai suatu realitas. Lihat: Soerjono Soekanto dan Sri Mamudji, Op.Cit., hlm. 2.

${ }^{34}$ Dengan pendekatan penelitian hukum, peneliti akan mendapatkan informasi dari berbagai aspek mengenai isu yang sedang dicoba untuk dicari jawabannya. Pendekatan-pendekatan yang digunakan di dalam penelitian hukum adalah 1 . pendekatan undang-undang (statute approach), 2. pendekatan kasus (case approach), 3. pendekatan historis (historical approach), 4. pendekatan komparatif (comparative approach), dan 5 . pendekatan konseptual (conceptual approach). Lihat Peter Mahmud Marzuki, Penelitian Hukum, Ed. Revisi, Cet. 8, Jakarta : Kencana, Prenada Media Grup, 2013, hlm. 133. Cara pendekatan tersebut dapat digabung sehingga dalam suatu penelitian hukum normatif dapat saja menggunakan dua pendekatan atau lebih yang sesuai, misalnya pendekatan perundang-undangan, pendekatan historis, dan pendekatan perbandingan. Lihat pula Jhonny Ibrahim, Teori Dan Metodologi Penelitian Hukum Normatif, Ed. Revisi, Cet. 3, (Malang: Bayumedia Publishing, 2007), hlm. 300 - 301.

ontologis lahirnya
perundang-undangan, $\begin{array}{r}\text { peraturan } \\ \text { landasan } \\ \text { filosofis peraturan perundang- } \\ \text { undangan, dan ratio legis ketentuan }\end{array}$

peraturan perundang-undangan yang berkenaan dengan pengaturan akta Notaris pada umumnya, dan secara khusus kedudukan akta Notaris sebagai akta dibawah tangan. ${ }^{35}$

Data $^{36}$ yang digunakan dalam penelitian ini adalah data sekunder ${ }^{37}$

${ }^{35}$ Pendekatan undang-undang (statute approach) dilakukan dengan menelaah semua undang-undang dan regulasi yang bersangkut paut dengan isu hukum yang sedang ditangani. Bagi penelitian untuk kegiatan praktis, pendekatan undang-undang ini akan membuka kesempatanbagi peneliti untuk mempelajari adakah konsistensi dan kesesuaian antara suatu undang-undang dengan undang-undang lainnya atau antara undang-undang dan Undang-Undang Dasar atau antara regulasi dan undang-undang. Hasil dari telaah tersebut merupakan suatu argumen untuk memecahkan isu yang dihadapi. Bagi penelitian untuk kegiatan akademis, peneliti perlu mencari ratio legis dan dasar ontologis lahirnya undang-undang tersebut. Dengan mempelajari ratio legis dan dasar ontologis suatu undang-undang, peneliti sebenarnya mampu menangkap kandungan filosofi yang ada di belakang undang-undang. itu. Memahami kandungan filosofi yang ada di belakang undang-undang itu, peneliti tersebut akan dapat menyimpulkan mengenai ada tidaknya benturan filosofis antara undangundang dengan isu yang dihadapi. Lihat Peter Mahmud Marzuki, Op.Cit., hlm. 133-134. Suatu penelitian normatif tentu harus menggunakan pendekatan perundang-undangan, karena yang akan diteliti adalah berbagai aturan hukum yang menjadi fokus sekaligus tema sentral suatu penelitian. Lihat pula Jhonny Ibrahim, Op.Cit., hlm. 302.

${ }^{36}$ Data, secara etimologis berasal dari bahasa Latin, dengan akar kata "do" yang artinya memberi; menunjukkan; menganugerahkan; menyerahkan. "data" adalah bentuk Jamak (Plural) dari "datum" yang Tunggal (Singular). Lihat Peter Mahmud Marzuki, Op.Cit., hlm. 59, dalam Catatan Kaki Nomor 8.

${ }^{37}$ Menurut tempat diperolehnya, data dalam penelitian dibedakan antara data primer dan data sekunder. Data primer adalah data yang diperoleh langsung dari masyarakat, sedangkan data sekunder 
yang diperoleh dari bahan hukum berupa Pertama, bahan hukum primer yang meliputi Undang-Undang Dasar Negara Republik Indonesia Tahun 1945, Kitab Undang-Undang Hukum Perdata, Undang-Undang Nomor 30 Tahun 2004 Tentang Jabatan Notaris, Undang-Undang Nomor 2 Tahun 2014 Tentang Perubahan Atas Undang-Undang Nomor 30 Tahun 2004 Tentang Jabatan Notaris. Kedua, bahan hukum sekunder yang meliputi literatur berupa kajian-kajian para ahli hukum berkenaan dengan akta Notaris pada umumnya, dan secara khusus kedudukan akta Notaris sebagai akta dibawah tangan, dan lainnya yang memiliki hubungan dengan pembahasan makalah ini. Ketiga, bahan hukum tersier yang berupa ensiklopedia dan kamuskamus.

Bahan-bahan hukum yang telah terkumpul kemudian diolah dan dianalisis dengan menggunakan metode penafsiran hukum dan metode konstruksi hukum.

Seluruh data yang berhasil dikumpulkan kemudian disortir dan diklasifikasikan, kemudian disusun melalui susunan yang komprehensif. Proses analisis diawali dari premispremis yang berupa norma hukum

adalah data yang diperoleh dari kepustakaan. Lihat Sri Mamudji, Et.al, Metode Penelitian Dan Penulisan Hukum, Cet. 1, (Depok: Badan Penerbit FH UI, 2005), hlm. 6. Adapun data sekunder tersebut memiliki ciriciri umum sebagai berikut: 1) data sekunder pada umumnya ada dalam keadaan siap terbuat (ready made); 2) bentuk maupun isi data sekunder telah dibentuk dan diisi oleh peneliti-peneliti terdahulu.; 3) data sekunder dapat diperoleh tanpa terikat atau dibatasi oleh waktu dan tempat. Dengan adanya data sekunder tersebut, seorang peneliti tidak perlu mengadakan penelitian sendiri dan secara langsung terhadap faktor-faktor yang menjadi latar belakang penelitiannya sendiri. Lihat pula: Soerjono Soekanto dan Sri Mamudji, Op.Cit., hlm. 24. positif yang diketahui dan berakhir pada analisis dengan menggunakan asas-asas hukum, doktrin-doktrin serta teori-teori.

Metode analisis data yang dipergunakan adalah metode analisis kualitatif. Penelitian kualitatif adalah penelitian yang bersifat menyeluruh dan merupakan satu kesatuan bulat (holistic), yaitu meneliti data yang diperoleh secara mendalam dari berbagai segi. ${ }^{38}$ Salah satu kekhususan dari penelitian kualitatif adalah lebih menekankan proses daripada hasil atau produk. ${ }^{39}$ Artinya, data yang diperoleh dan ditemukan dalam penelitian ini tidak selalu ditentukan oleh jumlah (kuantitas) peristiwa yang terjadi. Metode kualitatif ini digunakan karena penelitian ini tidak menggunakan konsep-konsep yang diukur atau dinyatakan dengan angka atau rumusan statistik. Dalam menganalisis data sekunder tersebut, penguraiaan data disajikan dalam bentuk kalimat yang konsisten, logis dan efektif serta sistematis sehingga memudahkan untuk interpretasi data dan kontruksi data serta pemahaman akan analisis yang dihasilkan.

$\begin{array}{lrr}\text { Pengolahan data pada hakikatnya } \\ \text { merupakan } & \text { kegiatan } & \text { untuk } \\ \text { mengadakan } \text { sistematisasi }^{40} & \text { terhadap }\end{array}$

${ }^{38}$ Norman K. Denzin \& Yvona S. Lincoln, ed. Handbook of Qualitative Research dikutip dari Natasya Yunita Sugiastuti, Tradisi Hukum Cina: Negara Dan Masyarakat (Studi Mengenai Peristiwa-peristiwa Hukum di Pulau Jawa Zaman Kolonial (1870-1942), Cet. 1, (Jakarta: Program Pasca Sarjana Fakultas Hukum Universitas Indonesia, 2003), hlm. 19.

${ }^{39}$ John W. Creswell. Research Design of Qualitative \& Quantitative Approches, dalam Natasya Yunita Sugiastuti, Ibid.

${ }^{40}$ Sistematisasi berarti membuat klasifikasi terhadap bahan-bahan hukum tersebut untuk memudahkan pekerjaan analisis dan konstruksi. Soerjono Soekanto (1), Pengantar Penelitian Hukum, Cet. 3, (Jakarta: UI Press, 1986), hlm. 251-252. 
bahan-bahan hukum. Data yang berupa pengaturan akta Notaris pada umumnya, dan secara khusus kedudukan akta Notaris sebagai akta dibawah tangan dalam peraturan perundang-undangan, disusun dalam bentuk narasi atau bercerita.

Hasil penelitian ini bersifat deskriptif analitis yaitu memaparkan, atau mengambarkan peraturan hukum yang berlaku dikaitkan dengan teoriteori hukum dan praktek pelaksanaan hukum positif. Deskripsi yang diberikan dalam penelitian ini adalah gambaran secara menyeluruh dan sistematis mengenai pengaturan akta Notaris pada umumnya, dan secara khusus kedudukan akta Notaris sebagai akta dibawah tangan. Sedangkan dikatakan analitis, karena akan dilakukan analisis terhadap berbagai aspek hukum yang mengatur tentang pengaturan akta Notaris pada umumnya, dan secara khusus kedudukan akta Notaris sebagai akta dibawah tangan.

Akhirnya sebagai cara untuk menarik kesimpulan dari hasil penelitian yang sudah terkumpul, digunakan metode berfikir deduktif. ${ }^{41}$ Dengan menggunakan metode deduktif akan selalu menempatkan kaidah hukum dalam peraturan perundangan, prinsip-prinsip hukum, dan ajaran atau doktrin hukum sebagai premis mayor dan fakta atau peristiwa hukum sebagai premis minor yang dirangkai secara sistematis sebagai susunan fakta-fakta hukum untuk memberikan

\footnotetext{
${ }^{41}$ Metode berpikir deduktif, yaitu pengambilan kesimpulan dari pernyataan yang bersifat umum ke suatu pernyataan yang bersifat khusus. Lihat: Winarno Surakhmad, Pengantar Penelitian Ilmiah, Dasar Metode dan Teknik, Ed. 7, (Bandung: Tarsito, 1984), hlm. 134.
}

gambaran tentang pengaturan akta Notaris pada umumnya, dan secara khusus kedudukan akta Notaris sebagai akta dibawah tangan. ${ }^{42}$

\section{Hasil Dan Pembahasan}

A. Pengaturan Keabsahan Akta Notaris Sebagai Akta Otentik

1. Syarat Materiil Dan Formil Suatu Akta Notaris

Notaris membuat akta harus sesuai dengan syarat formil dan materiil pembuatan akta, yaitu: ${ }^{43}$

a. Syarat formil:

1) Dibuat di hadapan pejabat yang berwenang, dalam hal ini notaris.

2) Dihadiri para pihak. (Pasal 39 UU JN)

3) Kedua belah pihak dikenal atau diperkenalkan kepada notaris. (Pasal 39 ayat is ispepi(2) UU JN)

4) Dihadiri oleh dua orang saksi. (Pasal 40 ayat (1) UU $\mathrm{JN})$.

5) Menyebut identitas notaris (pejabat), penghadap, dan para saksi. (Pasal 38 ayat (2), (3), dan (4) UU JN)

6) Menyebut tempat, hari, bulan dan tahun, jam pembuatan akta. (Pasal 38 ayat (2) UUJN)

7) Notaris membacakan akta di hadapan para penghadap. (Pasal 16 ayat (1) huruf 1 UU $\mathrm{JN})$

8) Ditandatangani oleh semua pihak. (Pasal 44 UU JN)

\footnotetext{
${ }^{43}$ M.Yahya Harahap, Op.cit., hlm. 649-655.
} 
Kedudukan Akta Notaris Sebagai Akta Di Bawah Tangan Berdasarkan Undang-Undang Jabatan Notaris
9) Penegasan pembacaan, penerjemahan dan penandatanganan pada bagian is-peppenutup akta. (Pasal 45 ayat (3) UU JN)

b. Syarat materiil:

1) Berisi keterangan kesepakatan para pihak.

2) Isi keterangan perbuatan hukum.

3) Pembuatan akta sengaja dimaksudkan sebagai alat bukti.

2. Kekuatan Pembuktian Akta Notaris

Suatu akta Notaris mempunyai 3 (tiga) macam kekuatan pembuktian, yaitu: ${ }^{44}$

a. Kekuatan pembuktian luar (uitwendige bewijskracht) yaitu syarat-syarat formal yang diperlukan agar akta Notaris dapat berlaku sebagai akta otentik.

b. Kekuatan pembuktian formal (formale bewijskracht) yaitu kepastian, bahwa suatu kejadian dan fakta tersebut dalam akta betul-betul dilakukan oleh Notaris atau diterangkan oleh pihak-pihak yang menghadap.

c. Kekuatan Pembuktian materiil (materiele bewijskracht) yaitu kepastian bahwa apa yang tersebut dalam akta tersebut merupakan pembuktian yang

\footnotetext{
${ }^{44}$ Habib Adjie (a), Sanksi Perdata dan Administrasi Terhadap Notaris Sebagai Pejabat Publik, (Bandung: Refika Aditama, 2007), hlm. 74.
}

sah terhadap pihak-pihak yang membuat akta atau mereka yang mendapat hak dan berlaku umum, kecuali ada pembuktian sebaliknya (tegenbewijs).

B. Pengaturan Kedudukan Akta Notaris Sebagai Akta Dibawah Tangan

Suatu akta otentik yang dimaksud dalam Pasak 1868 KUH Perdata, termasuk akta notaris yang diatur dalam Undang-Undang Jabatan Notaris, berdasarkan ketentuan Pasal $1869^{45}$ KUH Perdata, dapat kehilangan otentisitasnya dari semula akta otentik berubah dan turun (terdegradasi) menjadi dan berkedudukan sebagai akta di bawah tangan.

Apabila ditelaah secara seksama Undang-Undang Jabatan Notaris, ditemukan norma atau pengaturan bahwa suatu akta notaris dari semula akta otentik berubah dan turun (terdegradasi) menjadi dan berkedudukan sebagai akta di bawah tangan diatur dan berdasarkan Pasal $41,{ }^{46}$ Pasal 44 ayat (5), ${ }^{47}$ Pasal 48 ayat

${ }^{45} \mathrm{UU}$ Jabatan Notaris Pasal 1869 KUH Perdata "Suatu AKTA yang karena tidak berkuasa atau tidak cakapnya pegawai dimaksud di atas, atau karena suatu CACAT dalam BENTUKnya , TIDAK DAPAT DIPERLAKUKAN sebagai suatu AKTA OTENTIK, namun demikian mempunyai KEKUATAN sebagai TULISAN di BAWAH TANGAN jika ia DITANDATANGANI oleh Para PIHAK."

${ }^{46}$ UU Jabatan Notaris Pasal 41 "PELANGGARAN terhadap ketentuan sebagaimana dimaksud dalam Pasal 38, Pasal 39, dan Pasal 40 MENGAKIBATKAN Akta HANYA MEMPUNYAI KEKUATAN PEMBUKTIAN sebagai Akta Di Bawah Tangan."

${ }^{47}$ UU Jabatan Notaris Pasal 44 ayat (5) "PELANGGARAN terhadap ketentuan sebagaimana 
(3), ${ }^{48}$ Pasal 49 ayat (4), ${ }^{49}$ Pasal 50 ayat (5), ${ }^{50}$ Pasal 51 ayat (4), ${ }^{51}$ UndangUndang Jabatan Notaris.

\section{Analisis:}

\section{Analisis Terhadap}

Apabila Undang-Undang Jabatan Notaris ditelaah secara seksama, suatu akta notaris adalah sah dan

dimaksud pada ayat (1), ayat (2), ayat (3), dan ayat (4) mengakibatkan suatu Akta hanya mempunyai kekuatan pembuktian sebagai akta di bawah tangan dan dapat menjadi alasan bagi pihak yang menderita kerugian untuk menuntut penggantian biaya, ganti rugi, dan bunga kepada Notaris."

${ }^{48}$ UU Jabatan Notaris Pasal 48 ayat (3) "PELANGGARAN terhadap ketentuan sebagaimana dimaksud pada ayat (1) dan ayat (2) mengakibatkan suatu Akta hanya mempunyai kekuatan pembuktian sebagai akta di bawah tangan dan dapat menjadi alasan bagi pihak yang menderita kerugian untuk menuntut penggantian biaya, ganti rugi, dan bunga kepada Notaris."

${ }^{49}$ UU Jabatan Notaris Pasal 49 ayat (4) "PELANGGARAN terhadap ketentuan sebagaimana dimaksud pada ayat (1) dan ayat (2) mengakibatkan suatu Akta hanya mempunyai kekuatan pembuktian sebagai akta di bawah tangan dan dapat menjadi alasan bagi pihak yang menderita kerugian untuk menuntut penggantian biaya, ganti rugi, dan bunga kepada Notaris."

${ }^{50} \mathrm{UU}$ Jabatan Notaris Pasal 50 ayat (5) "Dalam hal ketentuan sebagaimana dimaksud pada ayat (1), ayat (2), ayat (3), dan ayat (4), serta dalam Pasal 38 ayat (4) huruf d TIDAK DIPENUHI, Akta tersebut hanya mempunyai KEKUATAN PEMBUKTIAN sebagai Akta di BAWAH TANGAN dan dapat menjadi alasan bagi pihak yang menderita kerugian untuk menuntut penggantian biaya, ganti rugi, dan bunga kepada Notaris."

${ }^{51}$ UU Jabatan Notaris Pasal 51 ayat (4) "PELANGGARAN terhadap ketentuan sebagaimana dimaksud dalam ayat (2) MENGAKIBATKAN suatu Akta hanya mempunyai kekuatan pembuktian sebagai akta di bawah tangan dan dapat menjadi alasan bagi pihak yang menderita kerugian untuk menuntut penggantian biaya, ganti rugi, dan bunga kepada Notaris." berkedudukan sebagai akta otentik sebagaimana dimaksud dalam Pasal 1 angka 7 UU Jabatan Notaris, apabila pembuatannya sesuai dan berdasarkan serta memenuhi ketentuan yang diatur antara lain dalam Pasal $38^{52}$; Pasal $39^{53}$; Pasal $40^{54}$; Pasal $44^{55}$ ayat (1),

${ }^{52}$ UU Jabatan Notaris Pasal 38 ayat (1) "Setiap Akta terdiri atas: iscepia. awal Akta atau kepala Akta; b. badan Akta; danisêp. akhir atau penutup Akta." ; ayat (2) "Awal Akta atau kepala Akta memuat: a. judul Akta; isteplo nomor Akta; bulan, dan tahun; danisepid. nama lengkap dan tempat kedudukan Notaris." ; ayat (3) "Badan Akta memuat: a. nama lengkap, tempat dan tanggal lahir, kewarganegaraan, pekerjaan, jabatan, kedudukan, tempat tinggal para penghadap dan/atau orang yang mereka wakili; b. keterangan mengenai kedudukan bertindak penghadap; c. isi Akta yang merupakan kehendak dan keinginan dari pihak yang berkepentingan; dan d. nama lengkap, tempat dan tanggal lahir, serta pekerjaan, jabatan, kedudukan, dan tempat tinggal dari tiap-tiap saksi pengenal." ayat (4) "Akhir atau penutup Akta memuat: a. uraian tentang pembacaan Akta sebagaimana dimaksud dalam Pasal 16 ayat (1) huruf $m$ atau Pasal 16 ayat (7); b. uraian tentang penandatanganan dan tempat penandatanganan atau penerjemahan Akta jika ada; c. nama lengkap, tempat dan tanggal lahir, pekerjaan, jabatan, kedudukan, dan tempat tinggal dari tiap-tiap saksi Akta; dan d. uraian tentang tidak adanya perubahan yang terjadi dalam pembuatan Akta atau uraian tentang adanya perubahan yang dapat berupa penambahan, pencoretan, atau penggantian serta jumlah perubahannya."

${ }^{53}$ UU Jabatan Notaris Pasal 39 ayat (1) "Penghadap harus memenuhi syarat sebagai berikut: a. paling rendah berumur 18 (delapan belas) tahun atau telah menikah; dan" ; b. cakap melakukan perbuatan hukum.; (2) "Penghadap harus dikenal oleh Notaris atau diperkenalkan kepadanya oleh 2 (dua) orang saksi pengenal yang berumur paling rendah 18 (delapan belas) tahun atau telah menikah dan cakap melakukan perbuatan hukum atau diperkenalkan oleh 2 (dua) penghadap lainnya." ; (3) "Pengenalan sebagaimana dimaksud pada ayat (2) dinyatakan secara tegas dalam Akta."

${ }^{54}$ UU Jabatan Notaris Pasal 40 ayat (1) "Setiap Akta yang dibacakan oleh Notaris dihadiri paling sedikit 2 (dua) orang saksi, kecuali peraturan perundang-undangan menentukan lain." (2) "Saksi sebagaimana dimaksud pada ayat (1) harus memenuhi 
ayat (2), ayat (3) dan ayat (4) ; Pasal $48^{56}$ ayat (1) dan ayat (2) ; Pasal $49^{57}$

syarat sebagai berikut: a. paling rendah berumur 18 (delapan belas) tahun atau sebelumnya telah menikah; b. cakap melakukan perbuatan hukum; c. mengerti bahasa yang digunakan dalam Akta; $d$. dapat membubuhkan tanda tangan dan paraf; dan f. tidak mempunyai hubungan perkawinan atau hubungan darah dalam garis lurus ke atas atau ke bawah tanpa pembatasan derajat dan garis ke samping sampai dengan derajat ketiga dengan Notaris atau para pihak." ayat (3) "Saksi sebagaimana dimaksud pada ayat (1) harus dikenal oleh Notaris atau diperkenalkan kepada Notaris atau diterangkan tentang identitas dan kewenangannya kepada Notaris oleh penghadap." ayat (4) "Pengenalan atau pernyataan tentang identitas dan kewenangan saksi dinyatakan secara tegas dalam Akta."

${ }^{55} \mathrm{UU}$ Jabatan Notaris Pasal 44 ayat (1) "Segera setelah Akta dibacakan, Akta tersebut ditandatangani oleh setiap penghadap, saksi, dan Notaris, kecuali apabila ada penghadap yang tidak dapat membubuhkan tanda tangan dengan menyebutkan alasannya." ; ayat (2) "Alasan sebagaimana dimaksud pada ayat (1) dinyatakan secara tegas pada akhir Akta." ; ayat (3) "Akta sebagaimana dimaksud dalam Pasal 43 ayat (3) ditandatangani oleh penghadap, Notaris, saksi, dan penerjemah resmi." ; ayat (4) "Pembacaan, penerjemahan atau penjelasan, dan penandatanganan sebagaimana dimaksud pada ayat (1) dan ayat (3) serta dalam Pasal 43 ayat (3) dinyatakan secara tegas pada akhir Akta."

${ }^{56}$ UU Jabatan Notaris Pasal 48 ayat (1) "Isi Akta dilarang untuk diubah dengan: a. diganti; b. ditambah; c. dicoret; d. disisipkan; e. dihapus; dan/atau; f. ditulis tindih." ; ayat (2) Perubahan isi Akta sebagaimana dimaksud pada ayat (1) huruf a, huruf b, huruf $\mathrm{c}$, dan huruf $\mathrm{d}$ dapat dilakukan dan sah jika perubahan tersebut diparaf atau diberi tanda pengesahan lain oleh penghadap, saksi, dan Notaris."

${ }^{57}$ UU Jabatan Notaris Pasal 49 ayat (1) "Setiap perubahan atas Akta sebagaimana dimaksud dalam Pasal 48 ayat (2) dibuat di sisi kiri Akta." ; ayat (2) "Dalam hal suatu perubahan tidak dapat dibuat di sisi kiri Akta, perubahan tersebut dibuat pada akhir Akta, sebelum penutup Akta, dengan menunjuk bagian yang diubah atau dengan menyisipkan lembar tambahan." ; ayat (3) "Perubahan yang dilakukan tanpa menunjuk bagian yang diubah mengakibatkan perubahan tersebut batal." ayat (1), ayat (2), dan ayat (3) ; Pasal $50^{58}$ ayat (1), ayat (2), ayat (3), dan ayat (4); Pasal $51^{59}$ ayat (1), ayat (2), dan ayat (3) Undang-Undang Jabatan Notaris.

Berkenaan dengan keabsahan suatu akta notaris dan konsekuensi hukumnya, pada pokoknya dapat diinventarisir sebagai berikut: ${ }^{60}$

a. Akta Batal Demi Hukum \{vide melanggar Ketentuan Pasal 16 ayat (1) huruf 1 , huruf $m$, Pasal 44, Pasal 48, Pasal 49, Pasal 50, Pasal 51 Undang-undang Nomor 2 Tahun 2014\}

${ }^{58}$ UU Jabatan Notaris Pasal 50 ayat (1) "Jika dalam Akta perlu dilakukan pencoretan kata, huruf, atau angka, pencoretan dilakukan sedemikian rupa sehingga tetap dapat dibaca sesuai dengan yang tercantum semula, dan jumlah kata, huruf, atau angka yang dicoret dinyatakan pada sisi kiri Akta." ; ayat (2) "Pencoretan sebagaimana dimaksud pada ayat (1) dinyatakan sah setelah diparaf atau diberi tanda pengesahan lain oleh penghadap, saksi, dan Notaris." ; ayat (3) "Dalam hal terjadi perubahan lain terhadap pencoretan sebagaimana dimaksud pada ayat (2), perubahan itu dilakukan pada sisi kiri Akta sesuai dengan ketentuan sebagaimana dimaksud dalam Pasal 49 ayat (2)." ; ayat (4) "Pada penutup setiap Akta dinyatakan tentang ada atau tidak adanya perubahan atas pencoretan."

${ }^{59} \mathrm{UU}$ Jabatan Notaris Pasal 51 ayat (1) "Notaris berwenang untuk membetulkan kesalahan tulis dan/atau kesalahan ketik yang terdapat pada Minuta Akta yang telah ditandatangani." ; ayat (2) "Pembetulan sebagaimana dimaksud pada ayat (1) dilakukan di hadapan penghadap, saksi, dan Notaris yang dituangkan dalam berita acara dan memberikan catatan tentang hal tersebut pada Minuta Akta asli dengan menyebutkan tanggal dan nomor Akta berita acara pembetulan." ; (3) "Salinan Akta berita acara sebagaimana dimaksud pada ayat (2) wajib disampaikan kepada para pihak."

${ }^{60}$ Habib Adjie (b), Kebatalan Dan Pembatalan Akta Notaris, Cet. 1, (Bandung: PT Refika Aditama, 2011), hlm. 63-88. 
b. Akta Dibatalkan oleh Para Pihak Sendiri dengan membuat Akta Pembatalan Akta.

c. Akta terdegradasi menjadi Akta dibawah Tangan

d. Akta Dibatalkan oleh Putusan Pengadilan yang telah berkekuatan hukum tetap karena penerapan asas praduga Sah.

2. Analisis Terhadap Kedudukan Suatu Akta Notaris Dari Semula Akta Otentik Berubah Dan Turun (Terdegradasi) Menjadi Dan Berkedudukan Sebagai Akta Di Bawah Tangan

Suatu akta notaris dari semula akta otentik berubah dan turun (terdegradasi) menjadi dan berkedudukan sebagai akta di bawah tangan, diatur dalam Undang-Undang Jabatan Notaris, dan berdasarkan :

a. Pasal 41 Undang-Undang Jabatan Notaris apabila akta notaris yang dibuat tersebut melanggar ketentuan yang diatur dalam Pasal 38, Pasal 39 dan Pasal $40 \quad$ Undang-Undang Jabatan Notaris;

b. Pasal 44 ayat (5) Undang-Undang Jabatan Notaris apabila akta notaris yang dibuat tersebut melanggar ketentuan yang diatur dalam Pasal 44 ayat (1), ayat (2), ayat (3) dan ayat (4) UndangUndang Jabatan Notaris;

c. Pasal 48 ayat (3) Undang-Undang Jabatan Notaris apabila akta notaris yang dibuat tersebut melanggar ketentuan yang diatur dalam Pasal 48 ayat (1) dan ayat
(2) Undang-Undang Jabatan Notaris;

d. Pasal 49 ayat (4) Undang-Undang Jabatan Notaris apabila akta notaris yang dibuat tersebut melanggar ketentuan yang diatur dalam Pasal 49 ayat (1), ayat (2), dan ayat (3) Undang-Undang Jabatan Notaris;

e. Pasal 50 ayat (5) Undang-Undang Jabatan Notaris apabila akta notaris yang dibuat tersebut melanggar ketentuan yang diatur dalam Pasal 50 ayat (1), ayat (2), ayat (3), dan ayat (4) UndangUndang Jabatan Notaris;

f. Pasal 51 ayat (4) Undang-Undang Jabatan Notaris apabila akta notaris yang dibuat tersebut melanggar ketentuan yang diatur dalam Pasal 51 ayat (1), ayat (2), dan ayat (3) Undang-Undang Jabatan Notaris.

Suatu akta notaris dari semula akta otentik berubah dan turun (terdegradasi) menjadi dan berkedudukan sebagai akta di bawah tangan diatur dan berdasarkan Pasal 41, Pasal 44 ayat (5), Pasal 48 ayat (3), Pasal 49 ayat (4), Pasal 50 ayat (5), Pasal 51 ayat (4) Undang-Undang Jabatan Notaris tersebut, akta notaris tersebut memiliki nilai kekuatan pembuktian sama dan serupa dengan akta di bawah tangan.

Konsekuensi hukum suatu akta notaris dari semula akta otentik berubah dan turun (terdegradasi) menjadi dan berkedudukan sebagai akta di bawah tangan adalah berlakunya semua ketentuan tentang akta di bawah tangan yang diatur 
Kedudukan Akta Notaris Sebagai Akta Di Bawah Tangan Berdasarkan Undang-Undang Jabatan Notaris

dalam buku IV KUH Perdata khususnya Pasal 1874 dan ketentuan hukum acara, khususnya Pasal 286 $\mathrm{RBg}$ ).

Dari segi hukum pembuktian, akta di bawah tangan memiliki 2 (dua) daya kekuatan pembuktian, yaitu: ${ }^{61}$

\section{a. Daya Kekuatan Pembuktian Formil}

1) Orang yang bertanda tangan dianggap benar menerangkan hal yang tercantum dalam akta konsekuensinya, siapa saja atau orang yang menandatangani akta di bawah tangan:

- dianggap benar menerangkan seperti apa yang dijelaskan dalam akta;

- mesti dianggap terbukti tentang adanya pernyataan dari penandatangan : Surat keterangan yang saya tandatangani benar berisi keterangan saya

- sehingga kekuaran pembuktian akta di bawah tangan meliputi kebenaran idendititas penandatangan, menyangkut kebenaran identitas orang yang meberi keterangan.

2) tidak mutlak untuk keuntungan pihak lain, karena dimungkinkan adanya pengingkaran isi dan tandatangan dalam akta di bawah tangan tersebut (Pasal 1876 KUH Perdata Jo. Pasal $189 \mathrm{RBg}$. b. Daya Pembuktian Materiil

1) Isi Keterang Yang Tercantum di dalamnya harus dianggap benar dan mengikat kepada diri penandatangannya.

2) Memiliki daya mengikat kepada Ahli Waris dan orang yang mendapat hak daripadanya (vide Pasal 1875 KUH Perdata Jo. Pasal 288 $\mathrm{RBg}$ )

Jika suatu akta notaris dipermasalahkan oleh para pihak dalam akta baik mengenai isi maupun keabsahannya, maka: ${ }^{62}$

a. para pihak datang kembali ke notaris untuk membuat akta pembatalan atas akta dimaksudkan tersebut, dan dengan demikian akta yang dibatalkan sudah tidak mengikat lagi bagi para pihak, dan para pihak menanggung segala akibat dari pembatalan tersebut.

b. jika para pihak tidak sepakat akta yang bersangkutan untuk dibatalkan dengan akta pembatalan, maka salah satu pihak dapat menggugat pihak lainnya dalam akta tersebut, dengan gugatan untuk mendegradasikan akta notaris menjadi akta di bawah tangan. Setelah didegradasikan, maka Hakim yang memeriksa gugatan dapat memberikan penafsiran tersendiri atas akta notaris yang sudah didegradasikan, apakah tetap mengikat para pihak atau dibatalkan?. Hal ini tergantung pembuktian dan penilaian hakim. 
Tuntutan atau gugatan terhadap Notaris dalam bentuk penggantian biaya, ganti rugi, dan bunga sebagai akibat akta notaris mempunyai kekuatan pembuktian sebagai akta dibawah tangan atau batal demi hukum, berdasarkan adanya:

a. Hubungan hukum yang khas antara Notaris dengan para penghadap dengan bentuk sebagai perbuatan melawan hukum.

b. Ketidakcermatan, ketidaktelitian, dan ketidaktepatan dalam:

1) Teknik administratif membuat akta berdasarkan Undang-Undang Jabatan Notaris.

2) Penerapan berbagai aturan hukum yang tertuang dalam akta yang bersangkutan untuk para penghadap, yang tidak didasarkan pada kemampuan menguasai keilmuan bidang Notaris secara khusus dan hukum pada umumnya.

\section{Penutup}

A. Kesimpulan

Setelah menguraikan, mengkaji dan menganalisis Kedudukan Akta Notaris Sebagai Akta Dibawah Tangan, maka dapat disimpulkan sebagai berikut:

Pertama suatu akta notaris berkedudukan sebagai akta otentik apabila dibuat sesuai dengan ketentuan yang diatur dalam Pasal 38, Pasal 39, Pasal 40, Pasal 44 ayat (1), ayat (2), ayat (3) dan ayat (4), Pasal 48 ayat (1) dan ayat (2), Pasal 49 ayat (1) dan ayat (2) serta ayat (3), Pasal 50 ayat (1) ayat (2), ayat (3), dan ayat (4); Pasal 51 ayat (1), ayat (2), dan ayat (3) serta Pasal 16 Undang-Undang Jabatan Notaris.

Kedua suatu akta notaris dari semula akta otentik berubah dan turun (terdegradasi) menjadi dan berkedudukan sebagai akta di bawah tangan :

a. berdasarkan Pasal 41 UndangUndang Jabatan Notaris apabila pembuatan akta tersebut melanggar ketentuan yang diatur dalam Pasal 38, Pasal 39 dan Pasal $40 \quad$ Undang-Undang Jabatan Notaris;

b. berdasarkan Pasal 44 ayat (5) Undang-Undang Jabatan Notaris apabila pembuatan akta tersebut melanggar ketentuan yang diatur dalam Pasal 44 ayat (1), ayat (2), ayat (3) dan ayat (4) UndangUndang Jabatan Notaris;

c. berdasarkan Pasal 48 ayat (3) Undang-Undang Jabatan Notaris apabila pembuatan akta tersebut melanggar ketentuan yang diatur dalam Pasal 48 ayat (1) dan ayat (2) Undang-Undang Jabatan Notaris;

d. berdasarkan Pasal 49 ayat (4) Undang-Undang Jabatan Notaris apabila pembuatan akta tersebut melanggar ketentuan yang diatur dalam Pasal 49 ayat (1), ayat (2), dan ayat (3) Undang-Undang Jabatan Notaris;

e. berdasarkan Pasal 50 ayat (5) Undang-Undang Jabatan Notaris apabila pembuatan akta tersebut 
melanggar ketentuan yang diatur dalam Pasal 50 ayat (1), ayat (2), ayat (3), dan ayat (4) UndangUndang Jabatan Notaris;

f. berdasarkan Pasal 51 ayat (4) Undang-Undang Jabatan Notaris apabila pembuatan akta tersebut melanggar ketentuan yang diatur dalam Pasal 51 ayat (1), ayat (2), dan ayat (3) Undang-Undang Jabatan Notaris.

\section{B. Rekomendasi}

Berdasarkan kesimpulan yang telah dirumuskan di atas, maka dapat disarankan sebagai berikut:

Pertama perlu dipertegas pengaturan akta notaris sebagai akta otentik dalam Undang-Undang Jabatan Notaris, termasuk syarat formil dan materiil suatu akta notaris beserta konsekuensi hukum berupa akta notaris batal demi hukum apabila akta notaris dimaksud tidak memenuhi syarat materiil dan akta notaris dapat dibatalkan apabila akta dimaksud tidak memenuhi syarat formil, atau sebaliknya.

Kedua pengaturan kedudukan suatu akta notaris dari semula akta otentik berubah dan turun (terdegradasi) menjadi dan berkedudukan sebagai akta di bawah tangan yang diatur dalam Undang-Undang Jabatan Notaris perlu dipertegas lagi dengan tambahan norma bahwa kedudukan suatu akta notaris dari semula akta otentik berubah dan turun (terdegradasi) menjadi dan berkedudukan sebagai akta di bawah tangan dimaksud tersebut bukan pembatalan akta notaris.

\section{Daftar Pustaka}

\section{Buku:}

Adam, Muhammad Notaris Dan Bantuan Hukum, Bandung: Sinar Baru, 1985

Adjie, Habib (a). Sanksi Perdata dan Administrasi Terhadap Notaris Sebagai Pejabat Publik, cet. 1, Bandung: Refika Aditama, 2007

Adjie, Habib (a). Kebatalan Dan Pembatalan Akta Notaris, Cet. 1, Bandung: PT Refika Aditama, 2010

Daeng Naja, H.R. Teknik Pembuatan Akta (Buku Wajib Kenotariatan), Cet. 1, Yogyakarta: Pustaka Yustisia, 2012

Harahap, M. Yahya. Hukum Acara Perdata: Gugatan, Persidangan, Penyitaan, Pembuktian, dan Putusan Pengadilan, Ed. 2, Cet. 1, Jakarta: Sinar Grafika, 2017

Ibrahim, Jhonny. Teori Dan Metodologi Penelitian Hukum Normatif, Ed. Revisi, Cet. 3, Malang: Bayumedia Publishing, 2007

Kohar, A. Notaris dan Persoalan Hukum, (Surabaya: PT. Bina Indra Karya, 1985

Lumban Tobing, G.H.S. Peraturan Jabatan Notaris Di Indonesia, (Jakarta: PT Erlangga, 1980

Mamudji, Sri. Et.al, Metode Penelitian Dan Penulisan Hukum, Cet.1, Depok: Badan Penerbit FH UI, 2005

Marzuki, Peter Mahmud. Penelitian Hukum, Cet. 8, Jakarta : Kencana, Prenada Media Grup, 2013

Mertokusumo, Sudikno. Hukum Acara Perdata Indonesia, ç

Soekanto, Soerjono. Pengantar Penelitian Hukum, Cet. 3, Jakarta: UI Press, 1986 
Kedudukan Akta Notaris Sebagai Akta Di Bawah Tangan Berdasarkan

Undang-Undang Jabatan Notaris

Soekanto, Soerjono. dan Sri Mamudji, Soerjono Soekanto dan Sri Mamudji, Penelitian Hukum Normatif Suatu Tinjauan Singkat, Ed. 1., Cet. 5, Jakarta: PT. RajaGrafindo Persada, 2001.

Soemitro, Ronny Hanitijo. Metodologi Penelitian Hukum Dan Jurimetri, Cet. ke-3, Jakarta: Ghalia Indonesia, 1988.

Subagyo, Joko. Metode Penelitian Dalam Teori Dan Praktek, Jakarta: Rineka Cipta, 2004

Subekti, R. (a), Pokok-Pokok Hukum Perdata, Cet. 15, Jakarta: PT. Intermasa, 1980

Subekti, R. (b), Hukum Pembuktian, Cet. 8, Jakarta: Penerbit Pradnya Paramita, 1987

Sugiastuti, Natasya Yunita. Tradisi Hukum Cina: Negara Dan Masyarakat (Studi Mengenai Peristiwa-peristiwa Hukum di Pulau Jawa Zaman Kolonial (18701942), Cet. 1, Jakarta: Program Pasca Sarjana Fakultas Hukum Universitas Indonesia, 2003

Sunggono, Bambang. Metodologi Penelitian Hukum (Suatu Pengantar), Ed. 1., Cet. 3, Jakarta: PT. Raja Grafindo Persada, 2001

Surakhmad, Winarno Pengantar Penelitian Ilmiah,Dasar Metode dan Teknik, Ed. 7,, Bandung: Tarsito, 1984

Tedjosaputro, Liliana. Malpraktek Notaris dan Hukum Pidana, Semarang: CV. Agung, 1991

Thong Kie, Tan. Studi Notariat Dan SerbaSerbi Praktek Notaris, Cet. 2, (Jakarta: PT Ichtiar Baru van Hoeve, 2011

Tresna, Mr R. Komentar HIR, Cet. 18, Jakarta: PT Pradnya Paramita, 2005
Waluyo, Bambang. Penelitian Hukum Dalam Praktek, Ed. 1, Cet. 2, Jakarta: Sinar Grafika, 1996

\section{Perundang-undangan}

Indonesia, Undang-Undang Tentang Jabatan Notaris, UU No. 30 Tahun 2004, Lembaran Negara Republik Indonesia Tahun 2004 Nomor 117, Tambahan Lembaran Negara Republik Indonesia Nomor 4432.

------, Undang-Undang Tentang Perubahan Atas Undang-Undang Nomor 30 Tahun 2004 Tentang Jabatan Notaris, UU No. 2 Tahun 2014, Lembaran Negara Republik Indonesia Tahun 2014 Nomor 3, Tambahan Lembaran Negara Republik Indonesia Nomor 5491

\section{Kamus :}

Algra N.E., H.R.W. Gokkel,dkk, Kamus Istilah Hukum Fockema Andreae, Belanda Indonesia, [Fockema Andreas's rechtsgeleerd Handwoordenboek], diterjemahkan oleh Saleh Adi Winata, A Teloeki, H. Boerhanoeddin St Boen, Cet. 1, Bandung: Binacipta, 1983

H.R.W. Gokkel dan N. Van der wal, Istilah Hukum Latin Indonesia, [Juridish Latijn], diterjemahkan oleh S. Adi Winata, A Teloeki, H. Boerhamoeddin St Boen, Cet. 2, Jakarta: PT Intermasa, 1986 